\title{
Zwiększanie odporności kawitacyjnej stopów metali przez napawanie powłok
}

\author{
Improvement of cavitation erosion resistance of metal alloys \\ by pad welding of coatings
}

\section{Streszczenie}

W pracy przedstawiono wyniki pomiarów odporności na zużycie kawitacyjne powłok NiCrBSi oraz powłoki stellitowej. Powłoki na osnowie niklu wykonano metodą napawania płomieniowo-proszkowego, na osnowie kobaltu metodą TIG. Badania kawitacyjne wykonano na stanowisku wibracyjnym zgodnie z normą ASTM G-32. Na podstawie badań makroskopowych oraz przy użyciu mikroskopii elektronowej dokonano identyfikacji mechanizmu zużywania powłok. Określono cechy i właściwości wytworzonych powłok sprzyjające ich odporności kawitacyjnej. Powłoki na osnowie niklu wykazują wysoką odporność kawitacyjną i mogą być stosowane w celu zwiększania odporności elementów maszyn przepływowych.

Słowakluczowe:powłokina osnowienikluikobaltu, powłoka NiCrBSi, erozja kawitacyjna, metoda płomieniowo-proszkowa

\begin{abstract}
In the work results of cavitation erosion test of NiCrB$\mathrm{Si}$ and stellite coatings were presented. Nickel based coatings were pad welded with the oxy-acetylene powder torch, cobalt based with TIG method. Cavitation tests were conducted on vibratory test rig according do ASTM G-32 standard. The cavitation erosion mechanism was examined by using macroscopic and SEM microscopy observation. The influence of the microstructure features and properties of produced coatings on cavitation erosion resistance was investigated. Presented coatings can be applied to increase erosion resistance of fluid machine elements.
\end{abstract}

Keywords: nickel and cobalt based coatings, NiCrBSi coating, cavitation erosion, flame-powder pad welding

\section{Wstęp}

Żeliwo znajduje zastosowania jako materiał konstrukcyjny na części odlewane które mogą podlegać zużyciu kawitacyjnemu, takie jak obudowy i wirniki pomp. Uszkodzone elementy są wymieniane lub regenerowane. Jednym ze sposobów ochrony elementów przed zużyciem oraz wydłużenia okresu ich eksploatacji jest stosowanie powłok nadkładanych metodami cieplnymi.

Żeliwo szare odznacza się bardzo słabą odpornością na działanie kawitacji. Związane jest to z obecnością stosunkowo dużych wydzieleń miękkiego grafitu, który usuwany jest jako pierwszy, a powstałe ubytki przyśpieszają niszczenie osnowy metalowej $[1 \div 3]$. Prowadzone są prace z zakresu inżynierii powierzchni, których celem jest wytworzenie powłok i warstw zapewniających odpowiednią odporność kawitacyjną żeliwa. W literaturze spotyka się publikacje prezentujące wyniki badań odporności kawitacyjnej powierzchni odlewów stopowanych lub obrabianych laserowo [4], zbadany został wpływ obróbki cieplnej na odporność kawitacyjną [5,6], powtórnego przetapiania powierzchni [7], oraz znane są sposoby zwiększania odporności odlewów żeliwnych przy zastosowaniu powłok z tworzyw sztucznych [8].
W literaturze publikowano wyniki badań stopów metali lub powłok na bazie kobaltu i żelaza, powłok kompozytowych o osnowie niemetalowej $[9,10]$ przeznaczonych szczególnie w celu zabezpieczania powierzchni przed erozją kawitacyjną. Zużycie kawitacyjne powłok na osnowie niklu, wykazujących wysoką odporność na ścieranie, erozję i korozję [11] nie zostato dostatecznie zbadane. Do takich stopów należą materiały zaprezentowane w niniejszym artykule. Stosowanie powłok na osnowie niklu napawanych płomieniowo-proszkowo jest ekonomicznie uzasadnione. Szczególnie w przypadku pompy wirowej eksploatowanej w wodzie brudnej, zawierającej cząstki stałe. Takie warunki pracy prowadzą do zachodzenia złożonego procesu zużywania i obejmują zużycie korozyjne, ścierne i kawitacyjne.

Praca ma na celu przedstawienie wyników badań odporności kawitacyjnej powłok na osnowie niklu oraz określenie cech i właściwości wytworzonych powłok sprzyjających ich odporności kawitacyjnej.

\section{Metodyka badań, materiał do badań}

Powłokę 1 wykonano metodą TIG, użyto materiału dodatkowego w postaci pręta metalowego o składzie przedstawionym w Tabela I, napoina składała się z trzech warstw. Powłoki

Mgr inż. Mirosław Szala, dr hab. Tadeusz Hejwowski, prof. PL - Politechnika Lubelska. 
$2 \div 5$ na osnowie niklu wytworzono z komercyjnych proszków (Tabela I) metodą napawania płomieniowo-proszkową na płytach ze stali gat. S235JR. Parametry procesu wykonania powłok zawarto w Tabela II. Próbki wzorcowe wykonano ze stali węglowej oraz żeliwa (Tabela I).

Sposób przygotowania płyt próbnych przedstawiono w pracy [12]. Obrobione mechanicznie próbki mały wymiary $\varnothing 25 \times 10$ mm, w tym grubość powłok wynosiła ok. $3 \mathrm{~mm}$. Powierzchnię powłok przed badaniami kawitacyjnymi szlifowano i polerowano uzyskując wartość $R a \leq 0,08 \mu \mathrm{m}$ oraz $\mathrm{Rz} \leq 0,3 \mu \mathrm{m}$. Pomiaru chropowatości dokonano za pomocą profilometru SURTRONIC 3+ (prod. Taylor Hobson). Przygotowano po trzy próbki z każdego z materiałów oraz zmierzono ich twardość HV30.

Badania kawitacyjne prowadzono w oparciu o normę ASTM G32-03 [13] na stanowisku wibracyjnym opisanym w artykule [12] (rys. 1).

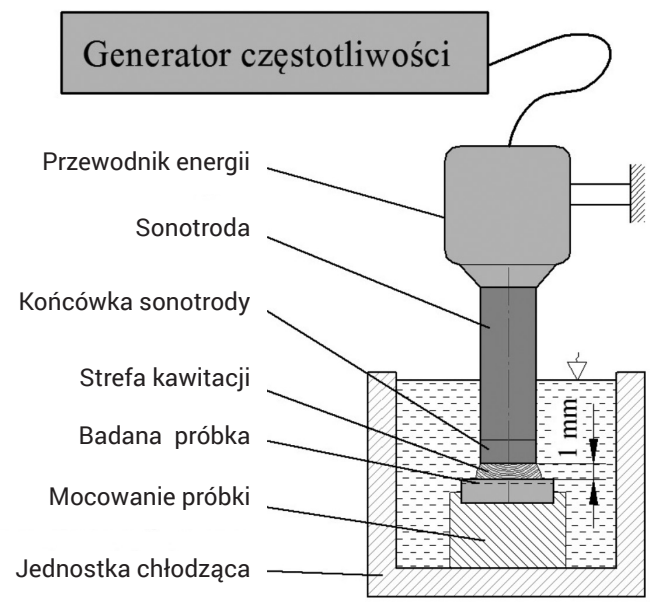

Rys. 1. Schemat urządzenia wibracyjnego

Fig. 1. Schematic diagram of ultrasonic equipment

Tablica II. Parametry wykonania powłok

Table II. Parameters of coatings deposition

\begin{tabular}{|c|c|c|c|}
\hline \multirow{2}{*}{$\begin{array}{c}\text { Typ } \\
\text { palnika }\end{array}$} & \multicolumn{2}{|c|}{ Ciśnienie gazu (MPa) } & \multirow{2}{*}{$\begin{array}{c}\text { Rodzaj } \\
\text { płomienia }\end{array}$} \\
\cline { 2 - 3 } & $\mathrm{O}_{2}$ & $\mathrm{C}_{2} \mathrm{H}_{2}$ & \\
\hline SPT-100 & $0,4 \pm 0,6$ & $0,04 \pm 0,06$ & Neutralny \\
\hline
\end{tabular}

Po określonych czasach ekspozycji wyznaczano ubytek masy próbek z dokładnością do 0,1 mg. Mierzono wartości parametrów profili chropowatości Ra oraz $\mathrm{Rz}$ w minimum 5 losowo wybranych obszarach na powierzchni zużycia kawitacyjnego każdej z próbek. Zmiany powstałe wskutek zużycia kawitacyjnego powierzchni próbek, obserwowano przy użyciu mikroskopu stereoskopowego Nikon 1500 oraz skaningowego mikroskopu elektronowego Phenom Pro X (prod. Phenom-World BV). Całkowity czas badań wynosił 300 minut. Obliczano średnią głębokość wżerów (MDE) wyznaczoną jako grubość materiału usuniętego na skutek erozji kawitacyjnej [13].

\section{Wyniki badań i ich dyskusja}

Powłoki na osnowie kobaltu stanową materiały wykazujące wysoką odporność na działanie kawitacji w porównaniu do stopów metali i powłok stosowanych w budowie maszyn przepływowych [10,14]. Najmniejsze zużycie odnotowano dla stellitowej powłoki 1 wykonanej metodą TIG (rys. 2). Mikrostruktura powłoki składa się z roztworu stałego na osnowie kobaltu, eutektyk i wydzieleń węglików wolframu i chromu. Pod wpływem oddziaływania kawitacji osnowa metalowa ulega przemianie i utwardzeniu - zwiększając odporność na zużywanie kawitacyjne napoiny [10]. Stosowanie powłok o składzie zbliżonym do składu stellitu 6 , nakładanych metodą TIG stanowi dość drogi ale skuteczny sposób zwiększania odporności kawitacyjnej.

Powłoki wytwarzane z proszków NiCrBSi zaliczane są do grupy samotopnikujących. Proszki użyte to wytworzenia napoin $2 \div 5$ zawierały $\mathrm{Cr}$, B i C sprzyjające tworzeniu twardych wydzieleń, które wpływają na wzrost odporności na różne rodzaje zużycia, Si poprawia zwilżalność i odtlenienia powłokę w trakcie procesu jej nakładania. Częściowo rozpuszczalne w roztworze stałym $\mathrm{Cr}$, Si i B obniżają temperaturę likwidusu stopu [15]. Bor dodawany jest w celu tworzenia eutektyki $\mathrm{Ni}-\mathrm{Ni}_{3} \mathrm{~B}$, cechującej się niską lepkością i powodującą wzrost zwilżalności metalu powłoki [16]. Stopy wieloskładnikowe o składzie NiCrBSi cechuje niska temperatura likwidusu na poziomie nawet $1060^{\circ} \mathrm{C}$, która jest niższa od temperatury topnienia staliwa co daje możliwość wytwarzania powłok na elementach żeliwnych. Układy pompowe, których elementy wykonane są jako odlewy żeliwne, pod wpływem działania kawitacji ulegają szybkiemu niszczeniu co może prowadzić do zakłócenia przepływu, spadku wydajności lub awarii.

Tablica I. Nominalne składy chemiczne materiałów dodatkowych wg danych producentów

Table I. Normalized chemical composition of powders according to manufacturer's data

\begin{tabular}{|c|c|c|c|c|c|c|c|c|c|}
\hline \multirow{2}{*}{ Numer } & \multirow{2}{*}{$\begin{array}{c}\text { Nazwa } \\
\text { handlowa/gatunek }\end{array}$} & \multicolumn{8}{|c|}{ Nominalny skład chemiczny wg danych producentów [\% wag.] } \\
\hline & & B & C & Co & $\mathrm{Cr}$ & $\mathrm{Fe}$ & $\mathrm{Ni}$ & Si & Inne \\
\hline 1 & MOST EL-Co 6 & - & 1,1 & bal. & 28 & 3,0 & 3 & 1,0 & $W=4,0$ \\
\hline 2 & Deloro Stellite 60 & 3,5 & 0,7 & - & 15 & 4,0 & bal. & 4,5 & - \\
\hline 3 & Amil AMI 1045 & 2,8 & 0,2 & - & 11,9 & 3,7 & bal. & 3,1 & - \\
\hline 4 & UTP EXBOND-2005 & 1,0 & 0,8 & - & 8 & 1,6 & bal. & 2,3 & $\begin{array}{l}\mathrm{Al}=0,3 \\
\mathrm{~W}=14,4\end{array}$ \\
\hline 5 & Colmonoy No. 237 & 1,3 & 0,2 & - & 4 & 0,5 & bal. & 2,8 & Inne=5,1 \\
\hline 6 & C45 & - & $\begin{array}{c}0,42- \\
0,5\end{array}$ & - & $\leq 0,3$ & bal. & $\leq 0,3$ & $0,1-0,4$ & $\begin{array}{c}M n=0,5-0,8 \\
S \leq 0,4 ; \\
P \leq 0,4 ; \\
M o \leq 0,1\end{array}$ \\
\hline 7 & EN-GJL-200 & - & $3,1-3,4$ & - & - & bal. & - & $1,9-2,3$ & $\begin{array}{c}M n=0,6-0,9 ; \\
P \leq 0,15 ; \\
S \leq 0,15\end{array}$ \\
\hline
\end{tabular}


Odporność kawitacyjna próbki żeliwnej 7 była ponad 10 krotnie niższa od odporności pozostałych badanych materiałów (rys. 2). Skumulowane wartości parametru MDA dla powłoki 5 i 4 były zbliżone do wartości otrzymanej dla wzorcowej próbki stalowej 6.

Powłoka na osnowie kobaltu wykazała kilkukrotnie wyższą odporność kawitacyjną od powłok na osnowie niklu.

Dla powłok na osnowie niklu $2 \div 5$, wraz ze wzrostem sumy zawartości B, C i Cr wzrasta odporność kawitacyjna (rys. 3). Wartość parametru MDE nie zależy od zmiany zawartości Si czy Fe. Dla powłoki 4 zawierającej WC obserwowano przyśpieszone zużywanie po najkrótszych czasach ekspozycji. Wykazywała ona gorszą odporność kawitacyjną od pozostałych powłok oraz próbki stalowej 6 ale znacznie mniejsze zużycie niż próbka żeliwna 7. Odporność kawitacyjna powłok na osnowie niklu wzrasta ze zwiększającą się zawartością $\mathrm{B}$ oraz $\mathrm{C}$ tworzących twarde wydzielenia oraz ze wzrostem udziału pierwiastków stopowych tworzących twarde cząstki lub umacniających osnowę. Wydaje się że dalsze zwiększanie odporności kawitacyjnej można uzyskać poprzez wzrost zawartości pierwiastków stopowych.

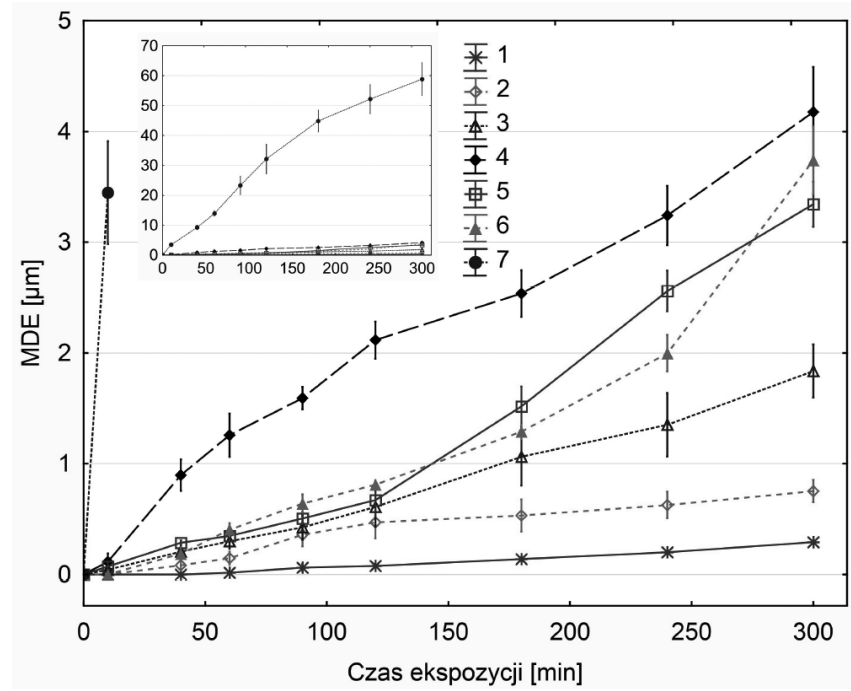

Rys. 2. Krzywe erozyjne badanych materiałów

Fig. 2. Cumulative erosion-time curves for elaborated materials

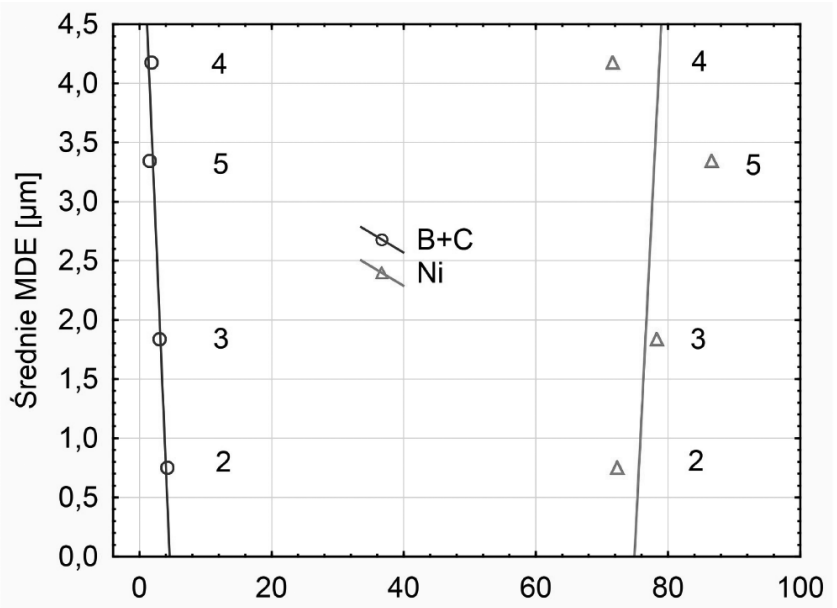

Rys. 3. Odporność kawitacyjna po 300 minutach badań w zależność od udziałów pierwiastków chemicznych

Fig. 3. Cavitation erosion resistance after 300 minutes of test vs content of selected chemical elements

Poddana działaniu kawitacji wypolerowana powierzchnia stopu metalu w pierwszym etapie erozji kawitacyjnej podlega zmatowieniu (utracie połysku). Związane jest to z powstawaniem mikronierówności na skutek trwałego odkształcania się warstwy wierzchniej materiału i załamywaniem promieni świetlnych w miejscach o większej chropowatości. Mikrodeformacje plastyczne inicjowane są w wyniku oddziaływania mikrostrumieni i fal uderzeniowych na poddaną kawitacji powierzchnię. Próbka 1 po godzinie badań kawitacyjnych w porównaniu do pozostałych badanych tworzyw, wykazywała nieznaczne zmatowienie powierzchni i stosunkowo wysoki połysk (rys. 4). Natomiast próbki $2 \div 5$ cechowało równomierne przemienienie powierzchni poddanej działaniu kawitacji, w porównaniu do pozostałych powłok niklowych powierzchnia próbki 2 cechowała się największym zmatowieniem powierzchni natomiast próbka 4 cechowało występowanie kraterów powstałe na skutek wykruszania się powłoki. Próbka referencyjna 6 wykazywała równomierne zmatowienie powierzchni a próbka 7, znacznie zerodowaną powierzchnię. Wzrost twardości materiałów sprzyja zmniejszeniu podatności na odkształcanie plastyczne powierzchni poddawanej działaniu kawitacji.
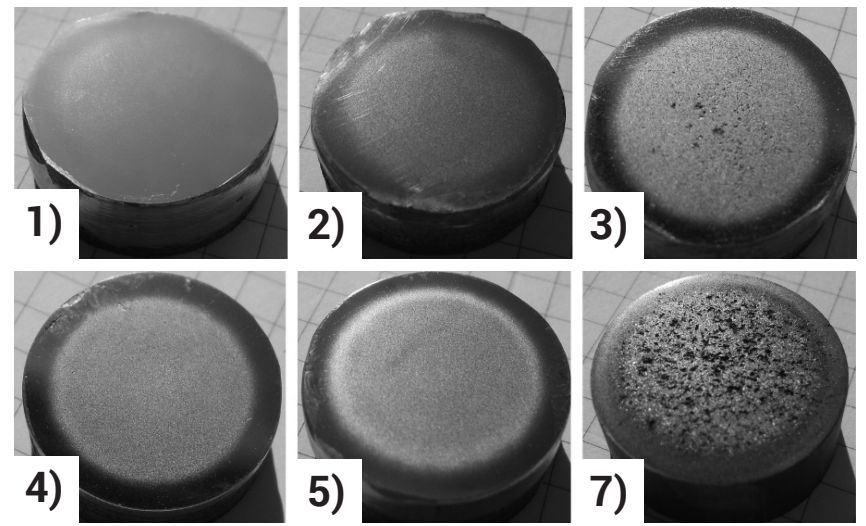

Rys. 4. Widok powierzchni wybranych próbek po godzinie badań kawitacyjnych

Fig. 4. Surface of selected specimens after 1 hour of cavitation

Powłoka 1 wykazywała po 2 godzinach badań (rys. 5) nieznaczne odkształcenie plastyczne zlokalizowane głównie wewnątrz dendrytów roztworu stałego kobaltu (rys. 5), odkształcone miejsca w późniejszych okresach ekspozycji podlegały erozji i przemianie w kratery. Niszczenie powłok na osnowie niklu rozpoczynało się we wcześniejszych czasach ekspozycji oraz uzyskiwano większe MDE niż dla powłoki kobaltowej. Dla każdej z powłok na osnowie

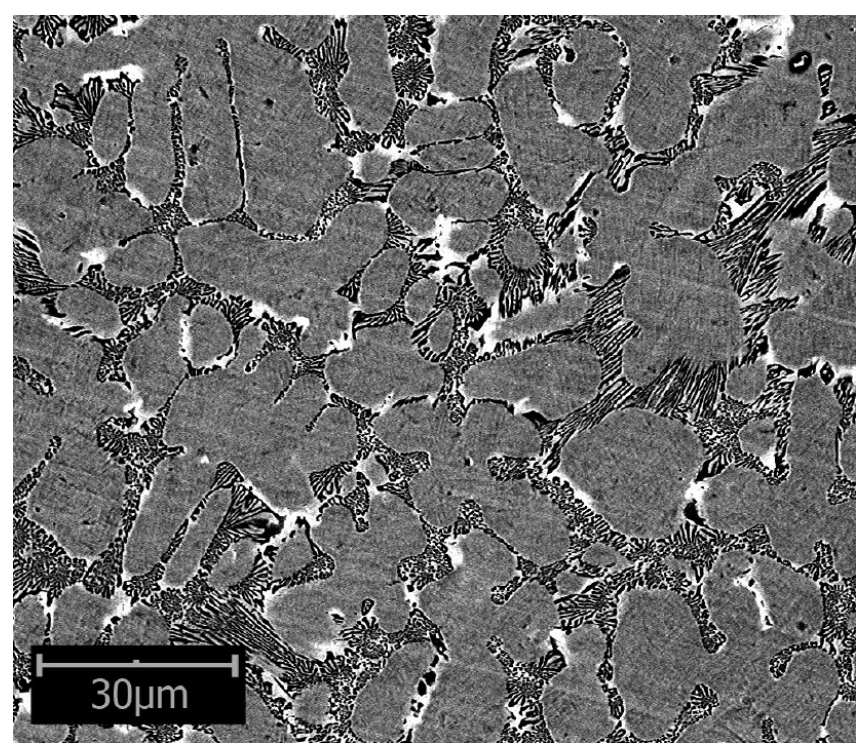

Rys. 5. Wybrany obszar powłoki 1 po 120 minutach badań kawitacyjnych (SEM)

Fig. 5. Selected area of coating 1 after 120 min of cavitation test (SEM) 
niklu, erozja inicjowana była odkształceniem plastycznym (o różnym stopniu przemienienia) roztworu stałego a w późniejszych okresach ekspozycji, ekstrakcji podlegały obszary na granicy wydzieleń twardych cząstek (węglików, borków) oraz roztworu stałego (rys. 6 i 8). W przypadku powłok o zbliżonym składzie chemicznym tj. 2-5 odporność kawitacyjna wzrasta ze wzrostem ich twardości, rysunek 9. Powłoka 4 zawierająca WC, wykazywała znacznie wyższe zużycie kawitacyjne pomimo wysokiej twardości. Związane było to z jej kompozytową budową mikrostrukturalną - składała się ona z osnowy metalicznej i fazy umacniającej zawierającej cząstki WC. W początkowym okresie ekspozycji cząstki te ulegały miejscowemu wykruszaniu się a później niszczona była osnowa powłoki 4 . Stwierdzono brak wystarczającego utwierdzenia cząstek w strukturze i usuwanie WC

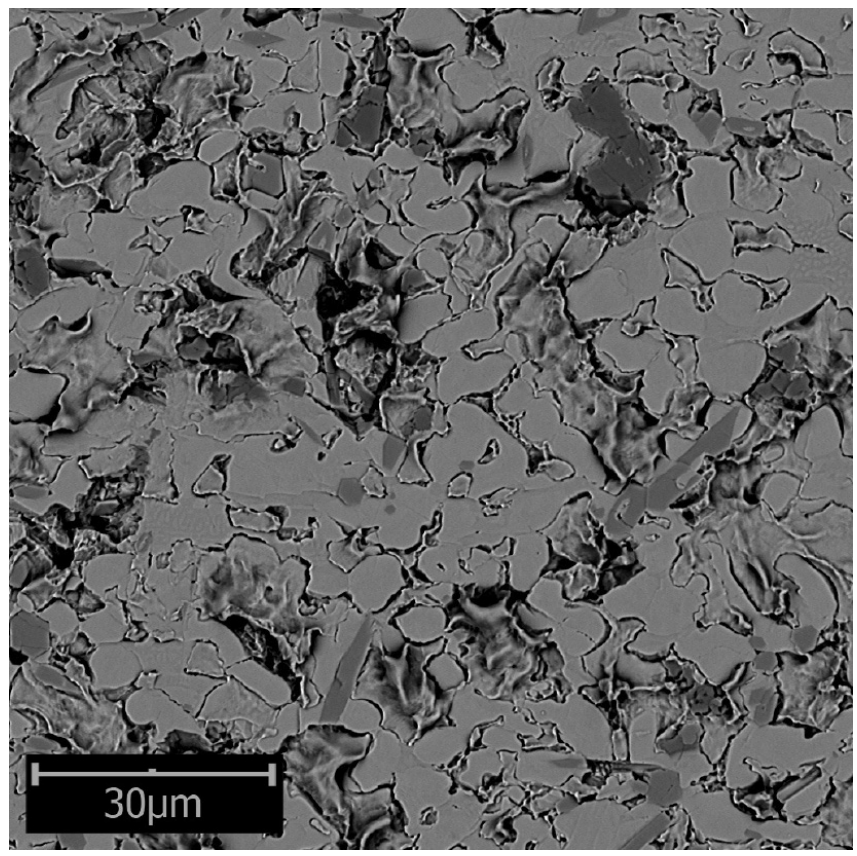

Rys. 6. Wybrany obszar powłoki 3 po 120 minutach badań kawitacyjnych (SEM)

Fig. 6. Selected area of coating 3 after 120 min of cavitation test (SEM)

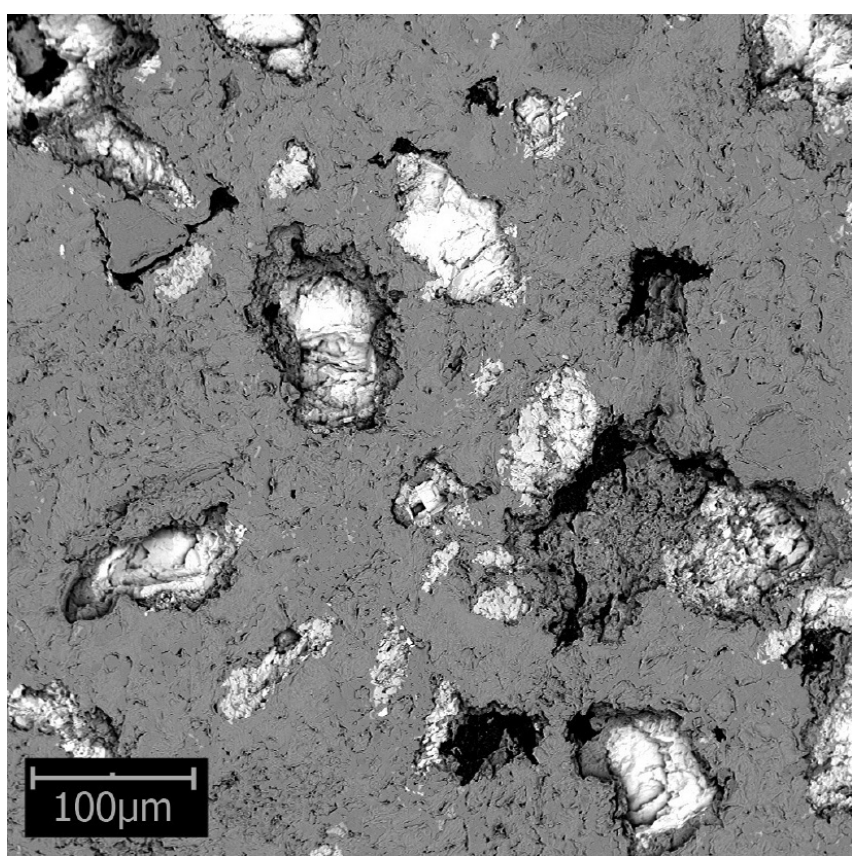

Rys. 7. Wybrany obszar powłoki 4 po 120 minutach badań kawitacyjnych (SEM)

Fig. 7. Selected area of coating 4 after 120 min of cavitation test (SEM)

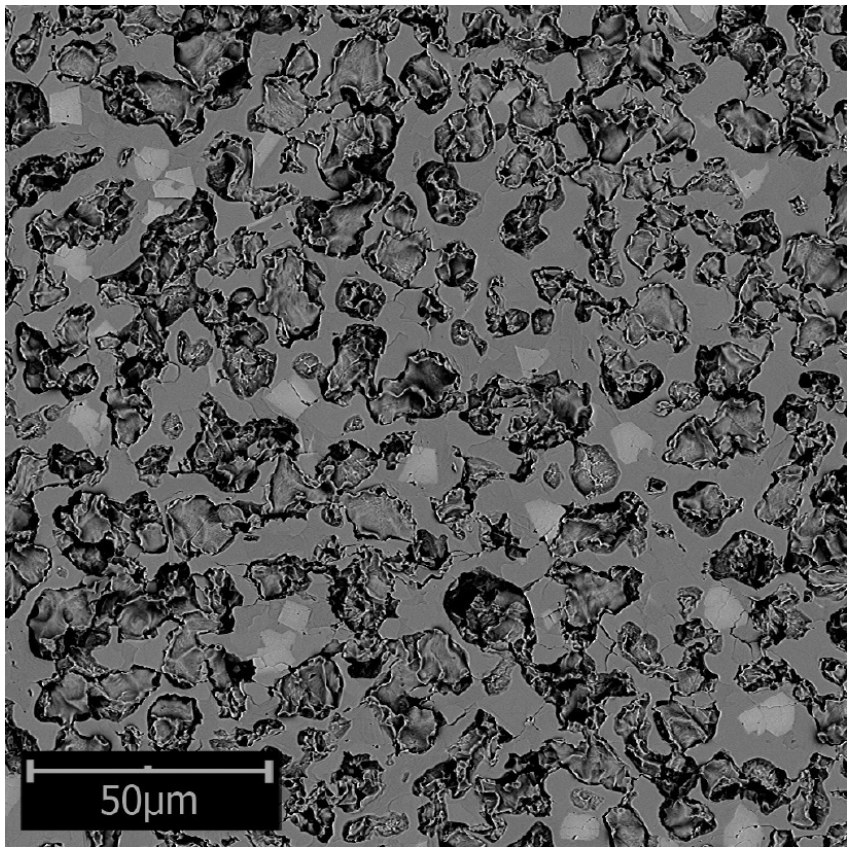

Rys. 8. Wybrany obszar powłoki 5 po 120 minutach badań kawitacyjnych (SEM)

Fig. 8. Selected area of coating 5 after 120 min of cavitation test (SEM)

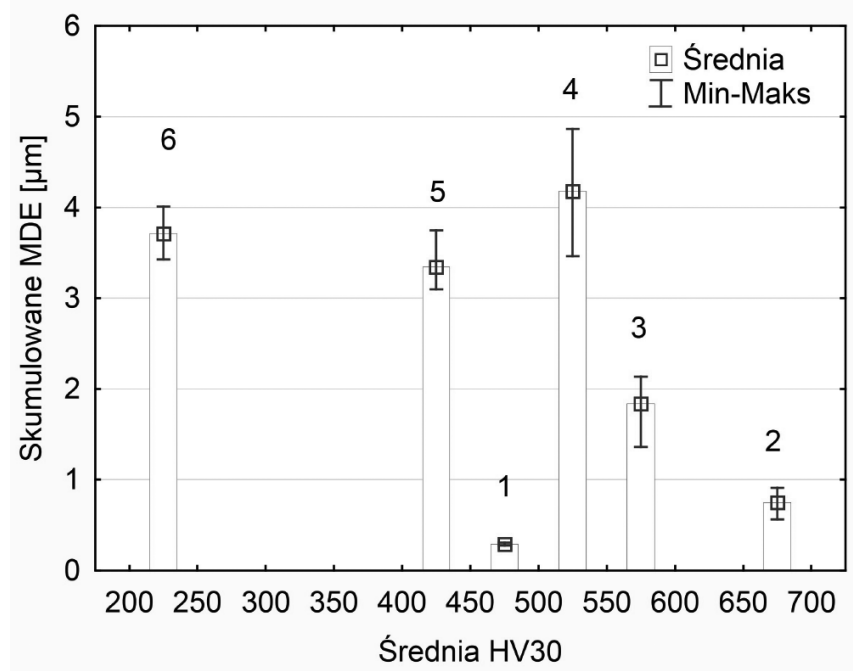

Rys. 9. Zależność skumulowanego MDE po 300 minutach badań od twardości

Fig. 9. Dependence of cumulated MDE after 300 minutes of test on hardness

w wyniku kruchego pękania (rys. 7). Dla powłok 2,3 w późniejszych okresach erozji niż dla powłoki 5 ekstrakcji wskutek erozji kawitacyjnej podlegały twarde cząstki borków, węglików chromu.

Zmiany powierzchni próbek po 300 minutach badań obserwowano na granicy obszaru oddziaływania kawitacji (rys. 10). Stwierdzono, że próbka stellitowa (1) wykazywała najmniej przemienioną powierzchnię, próbki 2 i 3 cechowało wyróżnienie składników mikrostrtukruralnych, szczególnie budowy dendrytycznej. Powierzchnie powłok 2 i 3 cechowałynie duże miejscowe ubytki materiłu w porównaniu do powłok 4, 5 i próbki żeliwnej. Powierzchnia stalowej próbki wzorcowej 6 podlegała równomiernej erozji kawitacyjnej, na całym obszarze oddziaływania kawitacji. Jakościowy opis zmian powierzchni badanych materiałów dobrze koresponduje z ilościowym opisem zużycia wyrażanym za pomocą krzywych erozyjych na rysunku 2 oraz zmian wartości parametrów Ra i Rz, rysunek 11. 


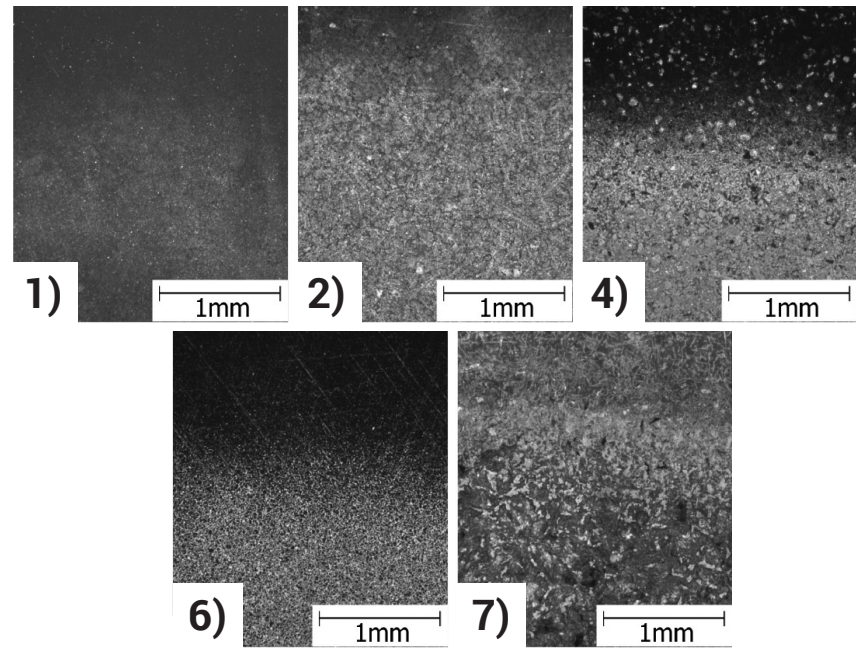

Rys. 10. Powierzchnia wybranych próbek na granicy obszaru oddziaływania kawitacji po, 300 minut. Dolna część zdjęcia - obszar przemieniony (mikroskop stereoskopowy)

Fig. 10. Surface of selected specimens at the interface of cavitation interaction after 300 minutes. At the bottom of a photo - modified area (stereoscopy microscope)

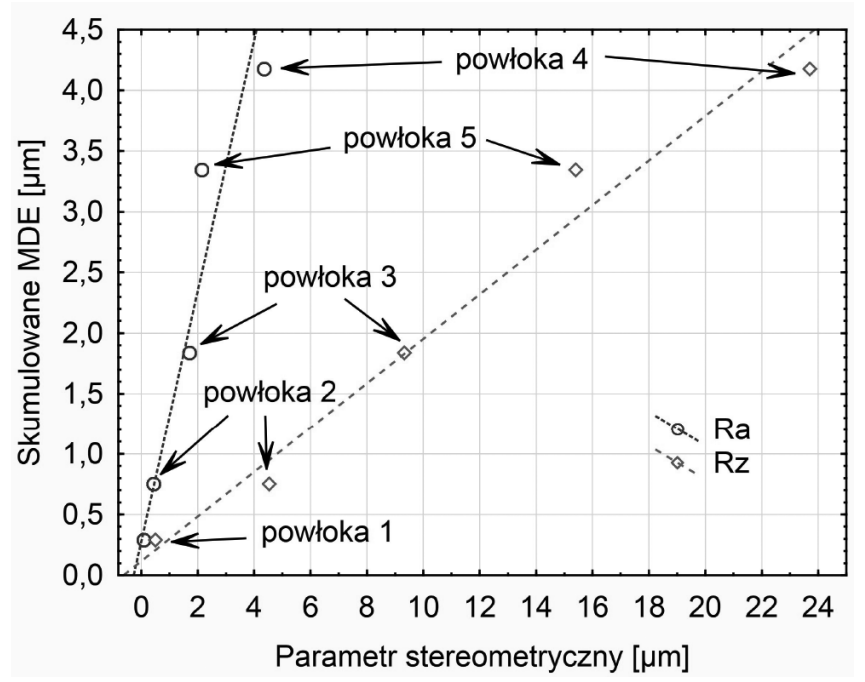

Rys. 11. Zależność MDE od parametrów Ra i Rz, 300 minut

Fig. 11. Dependence of MDE on Ra and Rz parameters, 300 minutes

\section{Podsumowanie}

Odporność kawitacyjna próbki żeliwnej była ponad 10 krotnie niższa od odporności pozostałych badanych materiałów. Powłoka kobaltowa wykazała kilkukrotnie wyższą odporność kawitacyjną od powłok na osnowie niklu, wiąże się to z zachodzeniem przemian fazowych osnowy oraz większym udziałem objętościowym twardych cząstek.

Wydaje się że zwiększanie odporności kawitacyjnej stopów niklu można uzyskać poprzez wzrost zawartości pierwiastków stopowych które umacniają roztwór stały i tworzą twarde wydzielenia. W przypadku powłok o osnowie niklowej odporność kawitacyjna wzrasta ze wzrostem ich twardości.

Erozja kwaitacyjna powłok na osnowie niklu inicjowana jest odkształceniem plastycznym (o różnym stopniu przemienienia) roztworu stałego. Następnie ekstrakcji podlegają obszary na granicy wydzieleń twardych cząstek (węglików, borków) i roztworu stałego. Cząstki węglika wolframu obecne w osnowie niklowej ulegały miejscowemu wykruszaniu, następnie niszczona była osnowa metalowa powłoki.

Badane stopy niklu ze względu na możliwość wytwarzania powłok metodami natryskiwania, natryskiwania z przetopieniem oraz napawania są interesujące do regeneracji żeliwnych elementów maszyn przepływowych.

\section{Literatura}

[1] T. Okada, Y. Iwai, A. Yamamoto, A study of cavitation erosion of cast iron, Wear. 84 (1983) 297-312. doi:10.1016/0043-1648(83)90271-5.

[2] S. Hattori, T. Kitagawa, Analysis of cavitation erosion resistance of cast iron and nonferrous metals based on database and comparison with carbon steel data, Wear. 269 (2010) 443-448. doi:10.1016/j. wear.2010.04.031.

[3] K. Steller, O mechanizmie niszczenia materiałów podczas kawitacji, IMP PAN, 1983.

[4] W.J. Tomlinson, M.G. Talks, Laser surface processing and the cavitation erosion of a 16 wt.\% Cr white cast iron, Wear. 139 (1990) 269284. doi:10.1016/0043-1648(90)90050-K.

[5] M. Dojcinovic, O. Eric, D. Rajnovic, L. Sidjanin, S. Balos, Effect of austempering temperature on cavitation behaviour of unalloyed ADI material, Materials Characterization. 82 (2013) 66-72. doi:10.1016/j. matchar.2013.05.005

[6] W.J. Tomlinson, M.G. Talks, Cavitation erosion of heat-treated low alloy cast irons, Wear. 137 (1990) 143-146. doi:10.1016/00431648(90)90023-4.

[7] S.P. Gadag, M.N. Srinivasan, Cavitation erosion of laser-melted ductile iron, Journal of Materials Processing Technology. 51 (1995) 150163. doi:10.1016/0924-0136(94)01601-V.

[8] G.L. García, V. López-Ríos, A. Espinosa, J. Abenojar, F. Velasco, A. Toro, Cavitation resistance of epoxy-based multilayer coatings: Surface damage and crack growth kinetics during the incubation stage, Wear. 316 (2014) 124-132. doi:10.1016/j.wear.2014.04.007.
[9] N. Qiu, L. Wang, S. Wu, D.S. Likhachev, Research on cavitation erosion and wear resistance performance of coatings, Engineering Failure Analysis. 55 (2015) 208-223. doi:10.1016/j.engfailanal.2015.06.003.

[10] M. Szkodo, Erozja kawitacyjna materiałów konstrukcyjnych metalowych, Wydawn. Politechniki Gdańskiej, 2008.

[11] T. Hejwowski, Nowoczesne powłoki nakładane cieplnie odporne na zużycie ścierne i erozyjne, Lublin University of Technology, 2013. http://bc.pollub.pl/dlibra/docmetadata?id=4059.

[12] M. Szala, T. Hejwowski, Odporność kawitacyjna powłok na osnowie niklu napawanych metodą płomieniowo-proszkową, Przegląd Spawalnictwa. (n.d.)

[13] ASTM G32-03 Standard Test Method for Cavitation Erosion Using Vibratory Apparatus, ASTM International, 2003.

[14] PN-86/H-04427 Erozja kawitacyjna: Badanie odporności materiałów metodą wibracyjną, Polski Komitet Normalizacji, Miar i Jakości, Warszawa, 1986.

[15] S.C. Li, Cavitation of Hydraulic Machinery, Imperial College Press, London, 2000.

[16] ASM handbook Volume 3: Alloy phase diagrams, ASM International, 1992.

[17] Z. Bergant, U. Trdan, J. Grum, Effect of high-temperature furnace treatment on the microstructure and corrosion behavior of NiCrBSi flame-sprayed coatings, Corrosion Science. 88 (2014) 372-386. doi:10.1016/j.corsci.2014.07.057. 